Електронне наукове фахове видання "Ефективна економіка" включено до переліку наукових фахових видань України з питань економіки (Категорія «Б», Наказ Міністерства освіти і науки України від 11.07.2019 № 975) www. economy.nayka.com.ua | № 5, 2020| 28.05.2020 p.

DOI: $10.32702 / 2307-2105-2020.5 .71$

УДК 657.6

\author{
M. Skoryk \\ PhD in Economics, Associate Professor, \\ Associate Professor of Department of Economic Theory, \\ University of the State Fiscal Service of Ukraine \\ ORCID ID: 0000-0003-3291-706X \\ S. Bohdan \\ Head of the Internal Audit Department, \\ Assistant of the Department of Management Accounting, Business Analytics and Statistics, \\ University of the State Fiscal Service of Ukraine \\ ORCID ID: 0000-0002-3249-7096

\section{RISK MANAGEMENT TOOLS IN THE SYSTEM OF PUBLIC FINANCIAL CONTROL}

\author{
М. О. Скорик, \\ к. е. н., дочент, дочент кафедри економічної теорії, \\ Університет державної фіскальної служби України \\ C. В. Богдан, \\ начальник відділу внутрішнього аудиту, \\ асистент кафедри управлінського обліку, бізнес-аналітики та статистики, \\ Університет державної фіскальної служби України

\section{ІНСТРУМЕНТИ РИЗИК-МЕНЕДЖМЕНТУ В СИСТЕМІ ДЕРЖАВНОГО ФІНАНСОВОГО КОНТРОЛЮ}

The article investigates the theoretical and methodological aspects of the use of risk management tools in the system of public financial control. It is proved that in modern conditions of reforming the approaches of public administration and administration the system of public financial control requires the creation on the basis of existing, including foreign experience, financial control mechanism, which will achieve the results in the formation and implementation of budgets. states. The urgency of the organization of financial control in the public finance system allows us to consider financial control as one of the most important elements of public reform in the country. It is substantiated that for the optimal use of financial, material and labor resources involved in the implementation of public financial control, as well as improving performance, regulatory authorities in organizing certain types of public financial control use a risk-based approach, which is to identify "risk areas" in activities of subjects of budget law. It is noted that the introduction of risk management in the implementation of state control in Ukraine should pursue such a goal as improving the effectiveness of control and audit activities. Improving the effectiveness of control, it is advisable to organize and exchange information about the results of control measures at all levels, which will also create conditions for mutual recognition of control results of each other's control activities and reduce resource costs for control activities. Aspects of influence of the state financial control on budgetary risk are defined. The COSO Enterprise Risk Model is considered 
and the characteristics of its components are given, namely: the component of the COSO Enterprise Risk Model "risk identification" and the component of the COSO Enterprise Risk Model "risk assessment". The method of application of the modified PEST-analysis in risk management in the system of the state financial control and the modified matrix of the SWOT-analysis for the purposes of risk management is resulted. A budget risk management card and its components have been compiled and characterized.

У статті досліджено теоретико-методичні аспекти застосування інструментів ризикменеджменту у системі державного фінансового контролю. Доведено, що у сучасних умовах реформування підходів публічного управління та адміністрування система державного фінансового контролю потребує створення на основі вже наявного, в тому числі зарубіжного досвіду, механізму фінансового контролю, метою якого буде досягнення заданих результатів при формуванні та виконанні бюджетів, щзо відповідає принципам фінансової політики держави. Актуальність питань організації фінансового контролю в системі публічних фінансів дозволяє розглядати фінансовий контроль в якості одного 3 найважливіших елементів державних реформ в країні. Обгрунтовано, що для оптимального використання фінансових, матеріальних $і$ трудових ресурсів, задіяних при здійсненні державного фінансового контролю, а також підвищення результативності діяльності, контролюючі органи при організачії окремих видів державного фінансового контролю застосовують ризик-орієнтований підхід, який полягає у визначенні «зон ризику» в діяльності суб'єктів бюджетного права. Зауважено, щзо впровадження ризик-менеджменту при здійсненні державного контролю в Україні має переслідувати таку мету, як підвищення ефективності контрольно-аудиторської діяльності. Визначено аспекти впливу державного фінансового контролю на бюджетний ризик. Виявлено, щуо існуючі на сьогодні міжнародні стандарти та вказівки щзодо організації державного внутрішнього фінансового контролю в державному секторі розроблені Інститутом внутрішніх аудиторів (IBA) та INTOSAI (Міжнародна організація вищих органів фінансового контролю). Розглянуто модель COSO Enterprise Risk Model та наведено характеристику ї̈ складових, а саме: компонент COSO Enterprise Risk Model «iдентифікація ризиків» та компонент COSO Enterprise Risk Model «оцінка ризиків». Зазначено, щзо основними складовими бюджетного ризику, щз можуть виникати у зовнішньому середовищі внаслідок певних чинників, на нашу думку, можуть виступати: правові, галузеві, інфляційні тощо; а у внутрішньому середовищі - професійні ризики, кадрові ризики, фінансові ризики. Ефективність механізмів фінансового контролю впливу на ризики досягається властивостями складовим елементів ризику $і$ якістю їх взаємодії, спрямованих на досягнення певного результату. Наведено методику застосування модифікованого PEST-аналізу в управлінні ризиками в системі державного фінансового контролю та модифікованої матрищі SWOT-аналізу в цілях управління ризиками. Складено та охарактеризовано картку управління бюджетним ризиком та його складовими.

Key words: financial control; public financial control; risk; budget risk; risk-oriented approach.

Ключові слова: фінансовий контроль; державний фінансовий контроль; ризик; бюджетний ризик; ризикоорієнтований підхід.

Problem statement. In modern conditions of reforming the approaches of public administration and administration, the system of public financial control requires the creation on the basis of existing, including foreign experience, financial control mechanism, which will achieve the results in the formation and implementation of budgets, which meets the principles of financial policy. The urgency of the organization of financial control in the public finance system allows us to consider financial control as one of the most important elements of public reform in the country. For the optimal use of financial, material and labor resources involved in the implementation of public financial control, as well as improving performance, regulatory authorities in organizing certain types of public financial control use a risk-oriented approach, which is to identify "risk areas" in the activities of sub ' budget law. It 
should be noted that the introduction of risk management in the implementation of state control in Ukraine should pursue such a goal as improving the effectiveness of control and audit activities.

Analysis of recent research and publications. The issue of public financial control is the subject of wide debate among such economists as N.P. Vladimirova, I.I. Ivanova, H.I. Ivaskevych, O.V. Natarova, I.E. Trush, A.W. Khmelnikov. At the same time, the issues of systematization of the use of risk management tools in the system of public financial control remain open.

Research objective. The purpose of the article is to systematize the theoretical and practical aspects of information management of risk management in the system of public financial control.

Research results. Internal control is a holistic process that depends on both management and staff, and involves a set of measures, such as distribution (delegation) of authority, risk management, monitoring the achievement of planned results, etc., aimed at providing sufficient guarantees to achieve certain goals activity of the organization, its effective implementation of functions and tasks [1, p. 16].

Risk-oriented approach in planning the activities of the internal state financial control in the financial and budgetary sphere is a method of organization and implementation of state control, in which the choice of intensity (frequency, duration, form) of control measures is determined by assigning the object of control to some extent the risk of damaging the budget system of Ukraine.

The main emphasis in the implementation of public financial control, in our opinion, should be placed on minimizing the risks of violations in the budget sphere and preventing harm to the state. Accordingly, the formed model of the state financial control should provide at all levels of budgetary system timely detection of risks of commission of violations of the legislation and their elimination, and also maintenance of effective management of budgetary risks.

For this purpose, an effective exchange of information on the results of control of risks identified in the financial and budgetary sphere, as well as on the measures taken to minimize them should be organized.

Based on the objectives, the model of public financial control at the state level should ensure the interaction of the Accounting Chamber, the State Audit Office as the highest body of external public audit, performing external public financial control, the Treasury as a body of internal financial control, the main managers of budget funds. financial control and internal financial audit, and other objects of control in the financial and budgetary sphere. To date, the bodies of external and internal public financial control operate independently of each other and do not form a single "control vertical", although there are obvious relationships between them that allow them to be considered within a single system. Interaction between all bodies of state financial control, as well as the main managers of budget funds should be carried out taking into account the need to exchange the following information:

- about the planned control measures for the purpose of elimination of their duplication; responsibility;

- on the results of control measures, including the measures taken to respond and bring to administrative

- on identified risks of violations or deviations from established standards and rules in the format of risk maps.

It should also be noted that the implementation of effective financial control is impossible without highquality interaction of public financial control bodies with the main managers of budget funds. In addition to the implementation of control measures, the State Treasury Service of Ukraine and the bodies of internal state financial control of the subjects of Ukraine conduct an analysis of the implementation of internal financial control and audit in relation to the chief administrators of the relevant budget. Within the framework of this mechanism, the possibility for the introduction of common principles and methods of control activities with internal state financial control is realized. The model of the impact of public financial control on budget risk is shown in Fig. 1. 


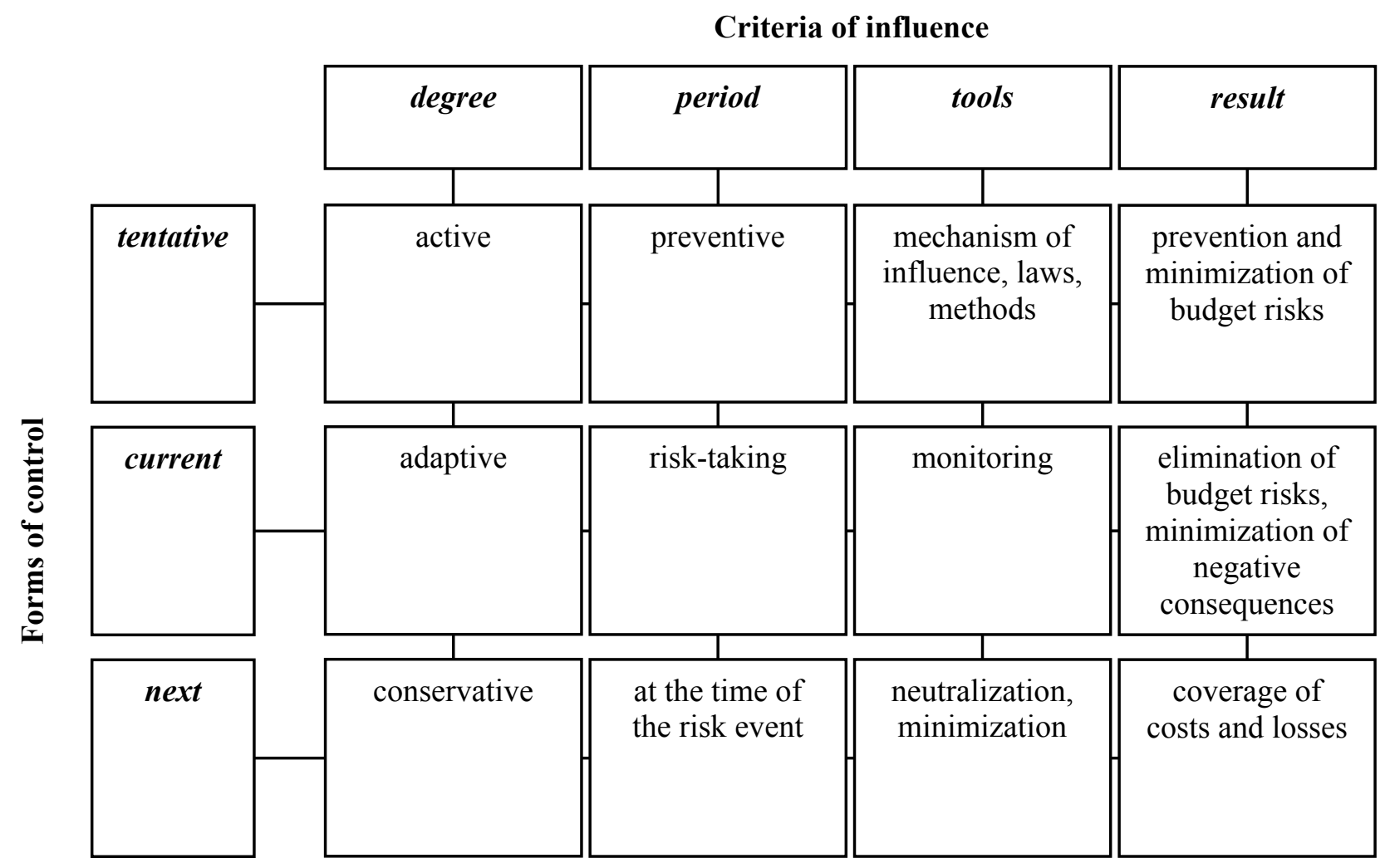

Fig. 1. The influence of public financial control on budgetary risk Source: compiled by the author.

Obviously, to increase the effectiveness of control, it is advisable to organize the exchange of information on the results of control measures at all levels, which will also create conditions for mutual recognition of control results of each other and reduce resource costs for control activities. Such information may, for example, include the exchange of information on identified risks in the financial and budgetary sphere in order to ensure a risk-oriented approach to control activities, as well as the implementation of tools to prevent violations.

Existing international standards and guidelines for the organization of public internal financial control in the public sector have been developed by the Institute of Internal Auditors (IBA) and INTOSAI (International Organization of Supreme Audit Institutions). The standards and guidelines developed by these international institutions for the organization of the internal control system in the public sector are based on the COSO Model, which was developed for the private sector and is the most common in business management [1, p. 16]. According to the COSO Internal ControlIntegrated Framework model, the control system consists of five interconnected components, each of which relates to business objectives (strategic, operational, reporting objectives and compliance with current legislation) [2, p. 1360]:

- control environment;

- risk identification and assessment system (Risk Assessment);

- control activities;

- information environment and communication system (Information and Communications);

- monitoring.

Subsequently, the COSO Enterprise Risk Model (ERM) was developed based on the COSO model, which combined the components of the internal control system and the components of the risk management system. The eight components of the risk management model include the previous five components of the conceptual framework for control, expanded to meet the growing demand for risk management (Table 1.). 
Table 1. Components of the COSO ERM internal control model

\begin{tabular}{|c|c|c|}
\hline № & Component & The essence and characteristics \\
\hline 1 & $\begin{array}{l}\text { Internal } \\
\text { environment }\end{array}$ & $\begin{array}{l}\text { the internal environment is the atmosphere in the organization and determines how the } \\
\text { risk is perceived by employees of the organization, and how they respond to it. The } \\
\text { internal environment includes the philosophy of risk management: risk appetite, honesty } \\
\text { and ethical values, as well as the environment in which they exist }\end{array}$ \\
\hline 2 & Objective setting & $\begin{array}{l}\text { goals should be defined before management begins to identify events that could } \\
\text { potentially affect their achievement. The risk management process ensures that } \\
\text { management has a properly organized process for selecting and setting goals, and that } \\
\text { these goals are consistent with the organization's mission and level of risk appetite. }\end{array}$ \\
\hline 3 & Event identification & $\begin{array}{l}\text { internal and external events that affect the achievement of the goals of the organization } \\
\text { should be determined taking into account their division into risks or opportunities. } \\
\text { Opportunities should be considered by management in the process of strategy formation }\end{array}$ \\
\hline 4 & Risk assessment & $\begin{array}{l}\text { risks are analyzed taking into account the probability of their occurrence and impact in } \\
\text { order to determine what action should be taken against them. Risks are assessed in } \\
\text { terms of inherent and residual risk }\end{array}$ \\
\hline 5 & Risk response & $\begin{array}{l}\text { management chooses a method of responding to risk - risk aversion, acceptance, } \\
\text { reduction or redistribution of risk - developing a number of measures to bring the risk } \\
\text { in line with the acceptable level and risk appetite of the organization }\end{array}$ \\
\hline 6 & Control activities & $\begin{array}{l}\text { policies and procedures designed and established in such a way as to ensure that risk } \\
\text { response is effective and timely }\end{array}$ \\
\hline 7 & $\begin{array}{l}\text { Information and } \\
\text { communications }\end{array}$ & $\begin{array}{l}\text { the necessary information is determined, recorded and transmitted in such a form and in } \\
\text { such terms that allow employees to perform their functional duties. There is also an } \\
\text { effective exchange of information within the organization both vertically from top to } \\
\text { bottom and from bottom to top, and horizontally }\end{array}$ \\
\hline 8 & Monitoring & $\begin{array}{l}\text { the entire risk management process of the organization is monitored and adjusted if } \\
\text { necessary. Monitoring is carried out as part of current management activities or through } \\
\text { periodic evaluations. }\end{array}$ \\
\hline
\end{tabular}

Source: compiled on the basis of [3].

As a result of the revision of the guidelines, the "goal setting" component was separated from the control environment component, and the COSO "risk assessment" component was divided into three: "risk identification", "risk assessment" and "risk response (or risk management) methods". [1, p. 17]. At the same time, in fact, the second COSO model is only a detail of the first. In the context of this, it is advisable to consider these components in more detail.

COSO Enterprise Risk Model component "risk identification". Under the identification and analysis of risks means identifying risks, their specifics due to the nature or other characteristics of risks, highlighting the features of their implementation (including the study of economic loss, as well as changes in risks over time, the degree of relationship between them and studies of influencing factors on them).

In the context of public financial control, the main complex concept is budget risk, which we propose to understand the threat of unforeseen budget losses due to violation (intentional non-compliance) of budgetary, economic and other legislation arising from external (independent) factors and internal (controlled) institutional environment.

The main components of budget risk that may arise in the external environment due to certain factors, in our opinion, may be: legal, sectoral, inflation, etc.; and in the internal environment - occupational risks, personnel risks, financial risks. The effectiveness of the mechanisms of financial control of the impact on risks is achieved by the properties of the components of the risk elements and the quality of their interaction, aimed at achieving a certain result.

The main methods of identifying the components of budget risk and their brief characteristics are shown in table 2 .

Table 2. The most common methods of risk identification

\begin{tabular}{|c|l|l|}
\hline № & \multicolumn{1}{|c|}{ Method name } & \multicolumn{1}{c|}{ The essence and characteristics } \\
\hline 1 & $\begin{array}{l}\text { Method of historical } \\
\text { analysis }\end{array}$ & $\begin{array}{l}\text { is to determine the similarity of the situation or document on which the risk is } \\
\text { determined, with those observed, used or prepared in the past }\end{array}$ \\
\hline 2 & Method of analogies & $\begin{array}{l}\text { based on the use of experience and experience gained by other government } \\
\text { agencies or authorities of other countries in similar (similar) situations }\end{array}$ \\
\hline 3 & Analytical method & $\begin{array}{l}\text { involves the use of technologies such as modeling, analysis of the scheme } \\
\text { "cause-effect" }\end{array}$ \\
\hline 4 & "Inverse analysis" method & $\begin{array}{l}\text { is to study the facts of inconsistency of planned indicators with their projected } \\
\text { sizes and to establish the reasons and external signs of these deviations, which in } \\
\text { the future will be possible to use to identify risks in the early stages of } \\
\text { administration }\end{array}$ \\
\hline 5 & Individual survey & $\begin{array}{l}\text { conducting surveys, including anonymous, participants or potential participants } \\
\text { in the process for which risks are identified }\end{array}$ \\
\hline
\end{tabular}

Source: compiled on the basis of [1]. 
Note that listed in table 2 methods of risk identification are common tools in the theory of risk management and can be used in the context of identifying the components of budget risk. COSO Enterprise Risk Model component "risk assessment". Assessment of budget risk and its components in the context of the functioning of the system of public financial control can be carried out by an expert method of assessment. Within the specified component it is possible to use the generally accepted methods of revealing of factors of external and internal environment in combination with the device of the theory of probabilities.

PEST-analysis is a strategic analysis tool that can be used to assess the impact of external factors - political $(\mathrm{P})$, economic (E), social (S) and technological (T) - on activities and identify the source of risks (Table 3).

Table 3. Modified PEST-analysis in risk management in the system of public financial control

\begin{tabular}{|c|c|c|c|c|c|c|c|}
\hline \multirow[t]{2}{*}{ № } & \multirow[t]{2}{*}{ Environmental factor } & \multirow{2}{*}{$\begin{array}{c}\text { Weighting } \\
\text { factor, } \\
d\end{array}$} & \multicolumn{3}{|c|}{$\begin{array}{c}\text { Expert } \\
\text { assessments, } a \\
(\text { Від } 0 \text { до 10) }\end{array}$} & \multirow{2}{*}{$\begin{array}{c}\text { Average } \\
\text { rating, } \\
\qquad \bar{a}\end{array}$} & \multirow[t]{2}{*}{$\begin{array}{l}\text { Weighted average } \\
\text { score }\end{array}$} \\
\hline & & & $\mathbf{E}_{1}$ & $\ldots$ & $\mathbf{E}_{\mathrm{j}}$ & & \\
\hline \multicolumn{8}{|c|}{ Political } \\
\hline $\mathrm{P}_{1}$ & $\ldots$ & $d_{l}$ & $E_{11}$ & $\ldots$ & $E_{l i}$ & $\overline{E_{1}}$ & $\overline{d_{1} \times \overline{E_{1}}}$ \\
\hline$\ldots$ & $\ldots$ & $\ldots$ & $\ldots$ & $\ldots$ & $\ldots$ & & \\
\hline $\mathrm{P}_{\mathrm{i}}$ & $\ldots$ & $d_{i}$ & $E_{i 1}$ & $\ldots$ & $E_{i j}$ & $\overline{E_{2}}$ & $d_{i} \times \bar{E}_{l}$ \\
\hline Tot & by group of factors $P$ & $\Sigma d_{i}$ & $\mathrm{x}$ & $\mathrm{x}$ & $\mathrm{x}$ & $\mathrm{x}$ & $P=\Sigma d_{i} \times \overline{E_{l}}$ \\
\hline \multicolumn{8}{|c|}{ Economic } \\
\hline$E_{1}$ & $\ldots$ & $d_{1}$ & $E_{11}$ & $\ldots$ & $E_{l j}$ & $\overline{E_{1}}$ & $\overline{d_{1} \times \overline{E_{1}}}$ \\
\hline & $\ldots$ & $\ldots$ & $\ldots$ & $\ldots$ & $\ldots$ & & $\ldots$ \\
\hline $\mathrm{E}_{\mathrm{i}}$ & ... & $d_{i}$ & $E_{i 1}$ & $\ldots$ & $E_{i j}$ & $\overline{E_{2}}$ & $d_{i} \times \bar{E}_{l}$ \\
\hline Tot & by group of factors $E$ & $\Sigma d_{i}$ & $\mathrm{x}$ & $\mathrm{x}$ & $\mathrm{x}$ & $\mathrm{x}$ & $E=\Sigma d_{i} \times \overline{E_{l}}$ \\
\hline \multicolumn{8}{|c|}{ Social } \\
\hline $\mathrm{S}_{1}$ & $\ldots$ & $d_{1}$ & $E_{11}$ & $\ldots$ & $E_{l j}$ & $\overline{\overline{E_{1}}}$ & $d_{1} \times \overline{E_{1}}$ \\
\hline & $\ldots$ & $\ldots$ & $\ldots$ & $\ldots$ & $\ldots$ & & \\
\hline $\mathrm{S}_{\mathrm{i}}$ & . & $d_{i}$ & $E_{i 1}$ & $\ldots$ & $E_{i j}$ & $\overline{E_{l}}$ & $d_{i} \times \bar{E}_{l}$ \\
\hline Tot & by group of factors $S$ & $\Sigma d_{i}$ & $\mathrm{x}$ & $\mathrm{x}$ & $\mathrm{x}$ & $\mathrm{x}$ & $S=\Sigma d_{i} \times \bar{E}_{l}$ \\
\hline \multicolumn{8}{|c|}{ Technological } \\
\hline $\mathrm{T}_{1}$ & $\ldots$ & $d_{1}$ & $E_{11}$ & $\ldots$ & $E_{l j}$ & $\overline{E_{1}}$ & $d_{1} \times \overline{E_{1}}$ \\
\hline & $\ldots$ & $\ldots$ & $\ldots$ & $\ldots$ & $\ldots$ & & \\
\hline $\mathrm{T}_{\mathrm{i}}$ & $\ldots$ & $d_{i}$ & $E_{i 1}$ & $\ldots$ & $E_{i j}$ & $\overline{E_{2}}$ & $d_{i} \times \bar{E}_{l}$ \\
\hline Tot & by group of factors $T$ & $\sum d_{i}$ & $\mathrm{x}$ & $\mathrm{x}$ & $\mathrm{x}$ & $\mathrm{x}$ & $T=\Sigma d_{i} \times \overline{E_{l}}$ \\
\hline Tot & points & 1,00 & $\mathrm{x}$ & $\mathrm{x}$ & $\mathrm{x}$ & $\mathrm{x}$ & $P+E+S+T$ \\
\hline
\end{tabular}

Source: compiled on the basis of [4].

Note that the proposed methodology does not limit the risk assessment experts in the number of factors for each group, but the sample should include the most significant factors.

SWOT-analysis is a classic risk management tool that considers strengths and weaknesses, opportunities and threats.

In order to manage risks, the SWOT-analysis matrix should be built with some modifications, including the inclusion of the following indicators:

- probability of occurrence of the event $\left(\mathrm{P}_{\mathrm{i}}\right)$ - from 0 to 1 due to the fact that the risk is a probabilistic value;

- expert assessment $\left(\mathrm{E}_{\mathrm{i}}\right)$ of the impact of each individual factor - from 1 to 10 ;

- the nature of the dependence of a pair of factors, expressed by the correlation coefficient (rF1-F2) with the values -1 - inverse, 1 - direct, 0 - no relationship;

- the degree of manifestation of the weak or strong side $\left(\mathrm{R}_{\mathrm{i}}\right)$ - from 0 to 10 .

Cross-assessment of the interaction of factors of individual groups of the external and internal environment in accordance with the parameters is found as follows:

$$
F_{1}+F_{2}=\sum_{i=1}^{n} P_{l} E_{i} R_{i} \times r_{F_{1}-F_{2}}
$$

The modified SWOT-analysis matrix for risk management purposes is shown in table 4 . 
Table 4. Modified matrix of SWOT-analysis for risk management purposes

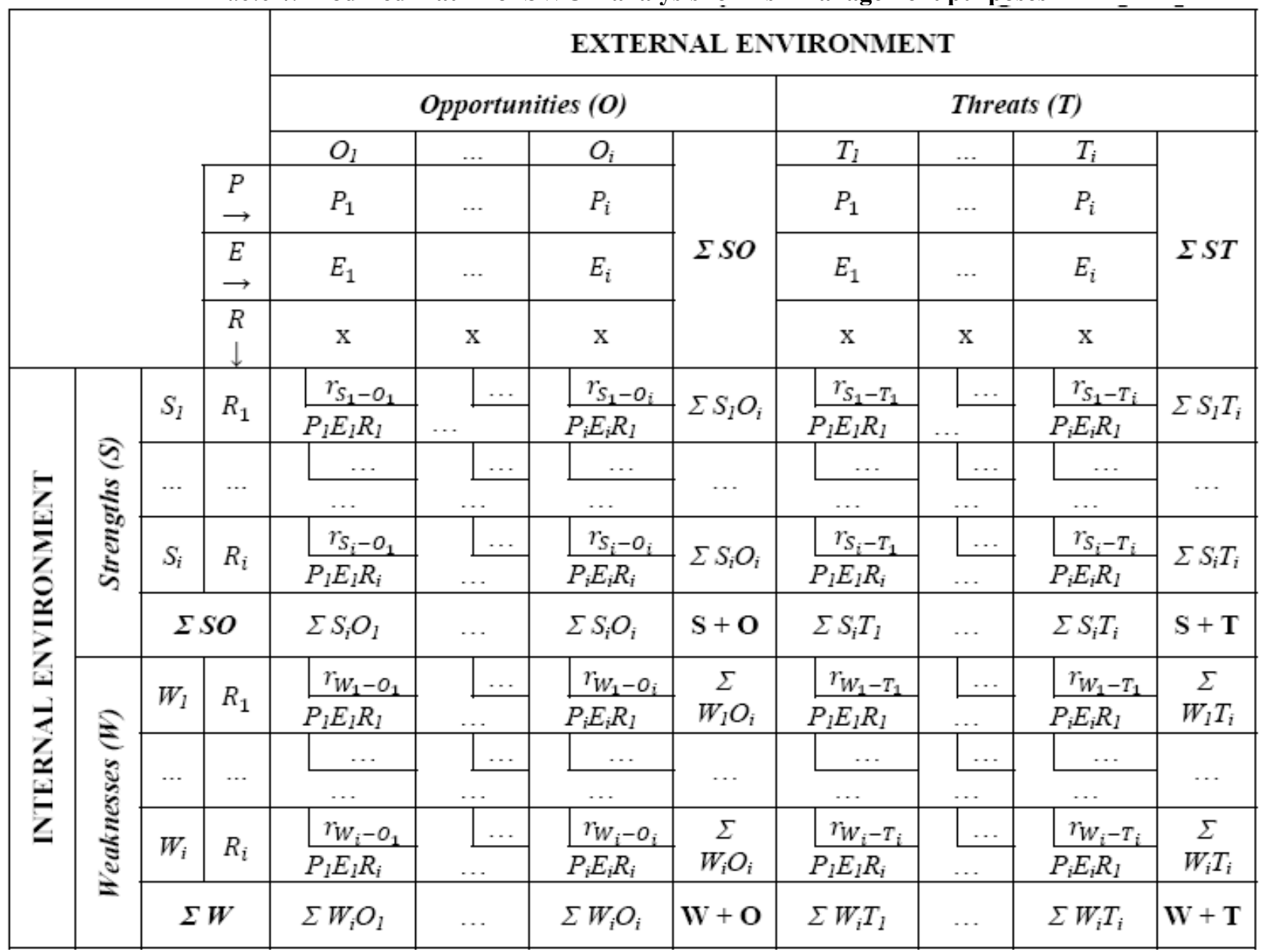

Source: compiled on the basis of [4].

The considered technique of modified SWOT-analysis is a simple and clear tool of information analysis and management decision-making, which can be used in the process of risk assessment in the system of public financial control.

COSO Enterprise Risk Model component "risk response methods". One of the tools that will regulate the development of risk response measures can be a risk management card, the template of which is shown in table 5.

Table 5. Budget risk management card and its components

\begin{tabular}{|c|c|c|c|c|}
\hline \multirow{2}{*}{ № } & \multirow{2}{*}{ Component of budget risk } & \multicolumn{3}{|c|}{ A set of actions aimed at: } \\
\hline & & risk reduction & risk hedging & risk avoidance \\
\hline 1 & information risk & $\begin{array}{c}\text { application of } \\
\text { information validation } \\
\text { procedures }\end{array}$ & $\begin{array}{l}\text { consultations with } \\
\text { budget managers }\end{array}$ & $\begin{array}{l}\text { constant monitoring } \\
\text { and analysis and } \\
\text { assessment of changes } \\
\text { in legislation }\end{array}$ \\
\hline 2 & organizational risk & $\begin{array}{l}\text { association of } \\
\text { structural subdivisions } \\
\text { in a common direction }\end{array}$ & $\begin{array}{l}\text { relationship and } \\
\text { cooperation of units in } \\
\text { solving problems }\end{array}$ & $\begin{array}{l}\text { monitoring and } \\
\text { evaluation of the } \\
\text { effectiveness of } \\
\text { structural units }\end{array}$ \\
\hline$\ldots$ & $\ldots$ & $\ldots$ & $\ldots$ & $\ldots$ \\
\hline $\mathrm{n}$ & personnel risk & $\begin{array}{c}\text { training and retraining } \\
\text { of staff }\end{array}$ & $\begin{array}{l}\text { involvement of young } \\
\text { professionals }\end{array}$ & $\begin{array}{l}\text { providing the best } \\
\text { parameters of } \\
\text { conditions and wages }\end{array}$ \\
\hline
\end{tabular}

Source: compiled by the author.

In order to manage the components of budget risk, the card shown above defines a set of actions aimed at reducing, hedging or avoiding the corresponding risk.

Conclusion. Thus, the proposed methods of identification, assessment and management of budgetary risk in the context of the functioning of the system of public financial control can act as information and analytical support in the activities of regulatory authorities. To increase the effectiveness of control, it is advisable to organize and exchange 
information on the results of control measures at all levels, which will also create conditions for mutual recognition by control bodies of the results of each other's control activities and reduce resource costs for control activities. Such information may, for example, include the exchange of information on identified risks in the financial and budgetary sphere in order to ensure a risk-oriented approach to control activities, as well as the implementation of tools to prevent violations.

\section{References.}

1. Tajnen, Ya. Andryeyev, P. and Chechulina, O. (2012), Derzhavny`j vnutrishnij finansovy`j kontrol’: Ukrayina ta yevropejs'ky`j dosvid [Public internal financial control: Ukraine and the European experience], Yevropejs ‘ky`j insty`tut derzhavnogo upravlinnya ta audy`tu, Kyiv, Ukraine.

2. Tytenko, L.V. (2018), "Management internal control in the system of economic security of the enterprise", Ekonomika ta suspil 'stvo, Vol. 19, pp. 1358-1363.

3. Committee of Sponsoring Organizations of the Treadway Commission (COSO) (2020), "Enterprise Risk Management - Integrated Framework”, available at: http://www.coso.org (Accessed 15 May 2020).

4. Tytenko, L.V. and Bohdan, S.V. (2019), "Analytical tools for risk management of tax consulting", Infrastruktura rynku, Vol. 28, pp. 359-367.

5. Kondukova, E.V. (2017), "Financial and analytical aspects of the risk-oriented approach in the practice of domestic control bodies", Ekonomichnyj analiz Vol 27. 2, pp. 105-110.

\section{Література.}

1. Тайнен Я., Андрєєв П., Чечуліна О. Державний внутрішній фінансовий контроль: Україна та європейський досвід. Свропейський інститут державного управління та аудиту. К. 2012. 183 с.

2. Титенко Л.В. Управлінський внутрішній контроль в системі забезпечення економічної безпеки підприємства. Економіка та суспільство. 2018. Вип. 19. С. 1358-1363

3. Enterprise Risk Management - Integrated Framework. Committee of Sponsoring Organizations of the Treadway Commission (COSO) URL: http://www.coso.org (дата звернення: 15 травня 2020)

4. Титенко Л.В., Богдан С.В. Аналітичний інструментарій управління ризиками податкового консультування. Інфраструктура ринку. 2019. №28. С. 359-367

5. Кондукова Е.В. Фінансово-аналітичні аспекти ризик-орієнтованого підходу у практиці вітчизняних контрольних органів. Економічний аналіз: Тернопіль. Видавничо-поліграфічний центр Тернопільського національного економічного університету «Економічна думка», 2017. Том 27. № 2. С. 105-110.

Стаття надійшла до редакції 15.05 .2020 p. 